\title{
GROWTH HORMONE SECRETION : ITS REGULATION AND THE INFLUENCE OF NUTRITIONAL FACTORS
}

\author{
RICHARD J. M. ROSS
}

Dept of Medicine, King's College School of Medicine, Bessemer Rd, London SE5 AND CHARLES R. BUCHANAN*

Dept of Growth and Development, Institute of Child Health, 30 Guilford St, London WCIN IEH

\section{CONTENTS}

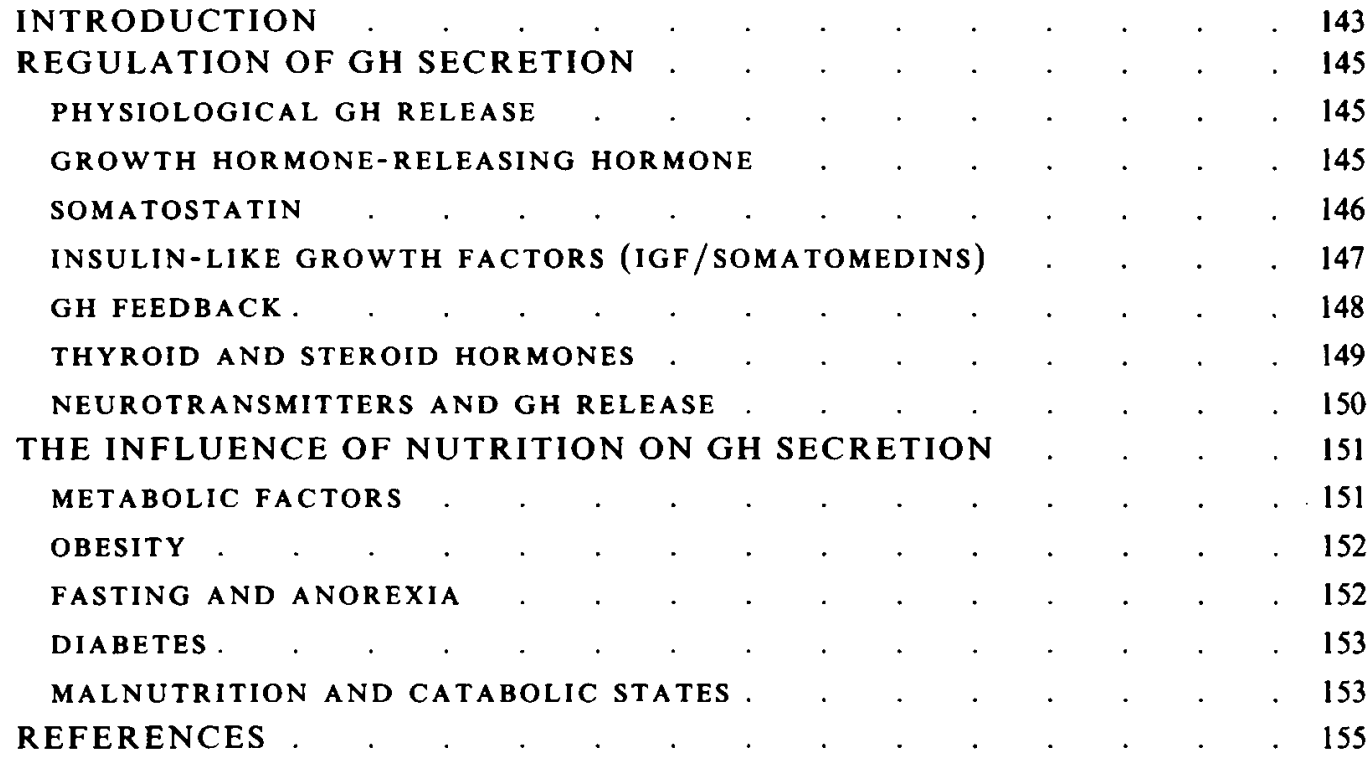

\section{INTRODUCTION}

Growth hormone (GH) has direct and indirect actions through which it stimulates growth of skeletal and other tissues, and influences the availability of metabolic fuels (Davidson, 1987; Isaksson et al. 1987). The growth promoting actions of $\mathrm{GH}$ are 'indirect' and are largely mediated through generation of the insulin-like growth factor, IGF-1, which may act both as an endocrine and paracrine hormone (Isaksson et al. 1987). The 'direct' actions of $\mathrm{GH}$ are predominantly antagonistic to insulin, although there are acute insulin-like effects of uncertain physiological significance (Fig. 1). Thus, there is an important interrelationship between the actions of GH, nutrition and growth.

GH is released from the human pituitary in a pulsatile manner. The pituitary has a unique anatomical relationship with the hypothalamus, such that the only blood supply to

\footnotetext{
* For reprints.
} 


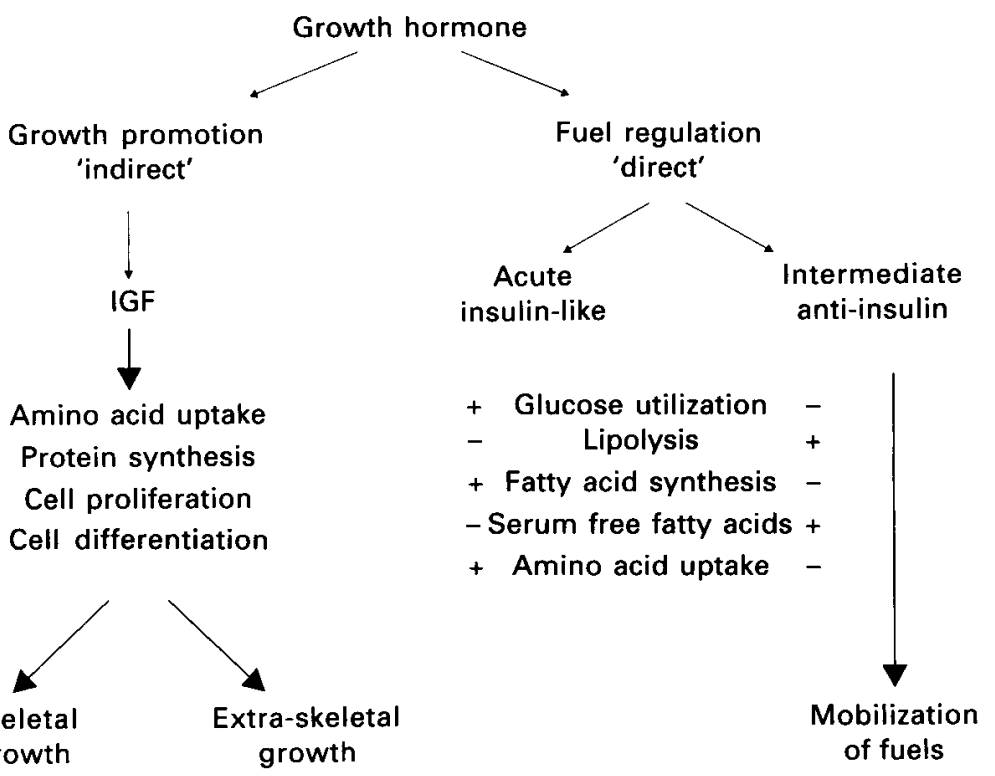

Fig. 1. Actions of growth hormone (GH). The growth-promoting effects are mediated predominantly through local tissue generation of insulin-like growth factor (IGF-1). Acute insulin-like effects have been demonstrated within $2 \mathrm{~h}$ of $\mathrm{GH}$ administration, before tissues become refractory to further $\mathrm{GH}$ exposure. The major impact of GH on fat and carbohydrate metabolism is, however, to antagonize the actions of insulin.

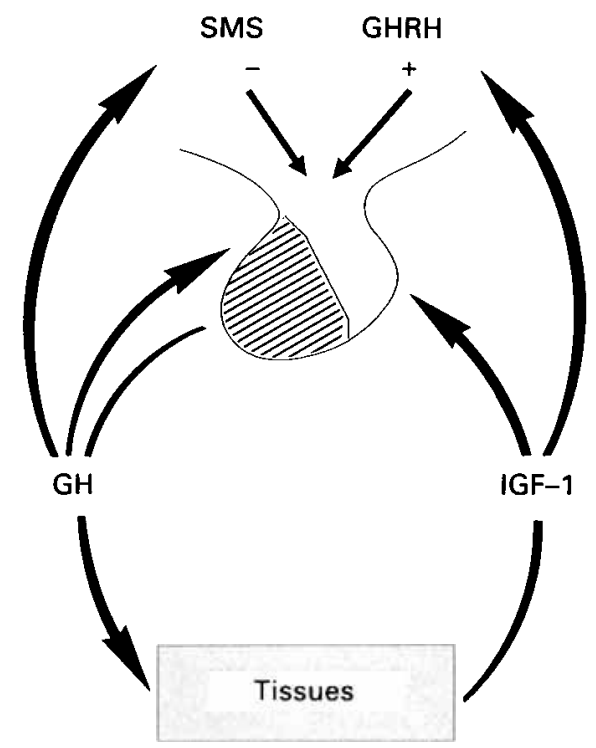

Fig. 2. Diagrammatic representation of feedback mechanisms on the hypothalamus and pituitary which regulate growth hormone (GH) and insulin-like growth factor (IGF) secretion. SMS, somatostatin; GHRH, growth hormone-releasing hormone. 
the anterior pituitary is derived from a portal venous system draining the hypothalamus. Thus, the hypothalamus can modulate release of anterior pituitary hormones by secreting various factors into this portal circulation. GH release is determined by a dynamic equilibrium between the inhibitory and stimulatory hypothalamic peptides, somatostatin (SMS) and growth hormone-releasing hormone (GHRH) (Fig. 2). The hypothalamic release of GHRH and somatostatin is, in turn, controlled through a complex network of neurotransmitters, and the hypothalamo-pituitary response may be influenced by age, sex, GH feedback, insulin, thyroid and steroid hormones, and nutritional status.

The GH-IGF-1 axis, therefore, includes the hypothalamic peptides, GH and IGF-1, and a complex network of feedback between the various hormones (Fig. 2). We will discuss the factors involved in the neuroendocrine regulation of GH secretion in man and how the influence of nutrition may modulate this system.

\section{REGULATION OF GH SECRETION}

\section{PHYSIOLOGICAL GH RELEASE}

$\mathrm{GH}$ is released in a pulsatile fashion with pulses occurring every $3-4 \mathrm{~h}$ with the greatest release during sleep (Quabbe et al. 1966). The amplitude and frequency of GH pulses is dependent on age, being greatest during puberty and declining with age (Finkelstein $e t$ al. 1972; Rudman et al. 1981; Martha et al. 1989). Sleep, stress, exercise, and post-prandial decline in blood glucose concentration act as stimuli to GH secretion, although it is likely that most episodes of release are spontaneous (Martin, 1976). The greatest secretion of GH occurs at night during sleep (Takahashi et al. 1968). Slow-wave sleep is frequently associated with GH release, but individual patterns of $\mathrm{GH}$ secretion during sleep show considerable heterogeneity (Adlard et al. 1987) and the time of sleep onset, rather than of slow-wave sleep, is more closely related to the nocturnal rise in GH secretion (Born et al. 1988). Martin (1976) concluded that GH release was a sleep-related event which probably should not be considered as closely linked to, or caused by, the neural process that subserves slow-wave sleep. A more specific basis for the association between sleep mechanisms and $\mathrm{GH}$ release has yet to be determined.

\section{GROWTH HORMONE-RELEASING HORMONE}

GHRH was the most recent of the hypothalamic regulatory peptides to be characterized (Guillemin et al. 1982; Rivier et al. 1982). Its existence had been proposed much earlier (Reichlin, 1961), but attempts to isolate it from animal hypothalami were unsuccessful because of the small quantities present and the coexistence of SMS, which interfered with the bioassays. GH-releasing factors were finally extracted from the pancreatic tumours of two patients in whom the ectopic production of GHRH had resulted in acromegaly (a condition arising from hypersecretion of $\mathrm{GH}$ ). Three homologous peptides varying in length from thirty-seven to forty-four amino acid residues were characterized:

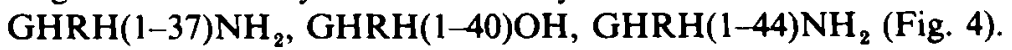

Peptides of both forty and forty-four residues have been extracted from human hypothalamic fragments and are identical to the pancreatic peptides (Ling et al. 1984). There has been considerable debate as to which is the native hormone, although it is likely that both the forty-four and forty residue peptides are important (Frohman \& Jansson, 1986). GHRH immunostaining has been demonstrated in the arcuate nucleus of the hypothalamus with fibres projecting to the median eminence and ending in contact with the portal vessels (Bloch et al. 1983). The human GHRH gene has been characterized and 


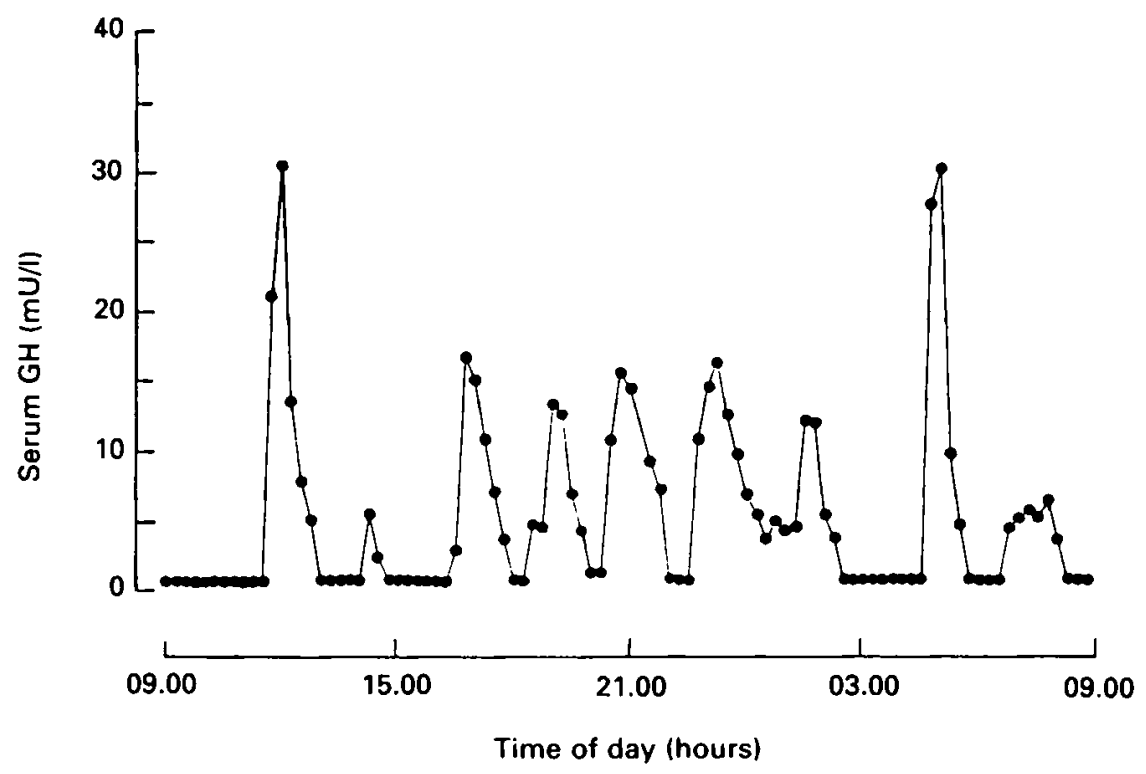

Fig. 3. Serum growth hormone (GH) levels over a $24 \mathrm{~h}$ period in a prepubertal boy. Blood samples were collected intermittently via an indwelling venous cannula at $15 \mathrm{~min}$ intervals.

mapped on chromosome 20 (Mayo et al. 1985). It has been demonstrated in vitro that GHRH stimulates not only GH secretion but also transcription of the GH gene (Barinaga et al. 1985). Transgenic transfer of the GHRH gene in mice results in enhanced growth (Hammer et al. 1985).

Specific receptors for GHRH have been demonstrated on rat pituitary cells in culture, and the GHRH receptor activates the adenylate cyclase-cAMP system (Frohman \& Jansson, 1986). GHRH given as an intravenous bolus selectively promotes GH release in normal subjects (Gelato et al. 1983; Grossman et al. 1983; Rosenthal et al. 1983), and antiGHRH antiserum blocks pulsatile GH release in the rat (Wehrenberg et al. $1982 a$ ). Studies in rats given GHRH after pretreatment with anti-somatostatin antiserum suggest that there is tonic secretion of both GHRH and somatostatin into hypophyseal portal blood. Superimposed on this are three- to four-hourly pulses of GHRH release which, in association with trough levels of SMS, generate pulses of GH (Tannenbaum \& Ling, 1984). Sampling of blood from the hypophyseal portal circulation of the rat confirms that SMS is continuously secreted but reaches trough levels at the time of $\mathrm{GH}$ release (Plotsky \& Vale, 1985).

\section{SOMATOSTATIN}

SMS was discovered when a substance that inhibited $\mathrm{GH}$ release was unexpectedly detected in rat hypothalami during the search for a growth hormone-releasing factor (Krulich et al. 1968). This factor was subsequently extracted from ovine hypothalamic fragments and proved to be a tetradecapeptide which was called 'somatostatin' (Brazeau et al. 1973) (Fig. 4). This name is perhaps inadequate; SMS possesses many physiological and pharmacological functions beyond the regulation of $\mathrm{GH}$ secretion. It is widely distributed within the nervous system, gut and both endocrine and exocrine glands, and it acts as a neurotransmitter as well as an endocrine hormone; for example, SMS is synthesized in the 


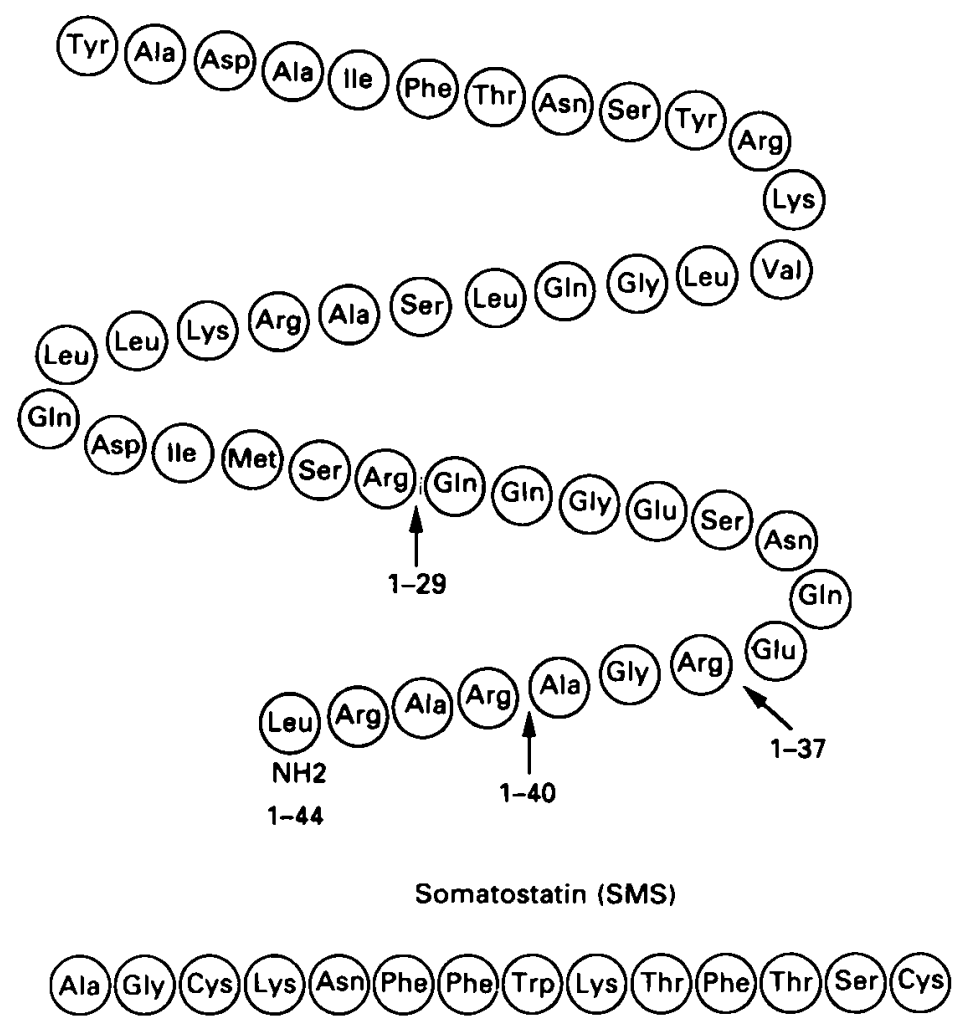

Fig. 4. Amino acid sequences of the various forms of growth hormone-releasing hormone and somatostatin.

pancreas and inhibits secretion of insulin, glucagon, and the exocrine secretions of the gut (for a full review, see Reichlin, 1983a,b).

There is now ample evidence for a physiological role of SMS in the control of GH secretion. The administration of anti-somatostatin antiserum increases trough levels of $\mathrm{GH}$ and, in rats, reverses the inhibitory effect on $\mathrm{GH}$ release of stress and starvation (Arimura et al. 1976; Terry \& Martin, 1981; Wehrenberg et al. 1982b). The simultaneous administration of SMS with GHRH blocks the GH response to GHRH in man (Davies et al. $1985 b$ ).

Both GHRH and SMS are found in the peripheral circulation. Some authors have suggested that these circulating plasma levels reflect hypothalamic secretion (Argente et al. 1987) but this seems unlikely, as circulating levels of GHRH and SMS are normal in GHdeficient children, show no relationship to GH levels, and are modulated by food intake (Sopwith et al. 1985, 1986, 1987; Rosskamp et al. 1987a). It is probable that peripheral levels of these hormones are largely derived from the gut.

\section{INSULIN-LIKE GROWTH FACTORS (IGF/SOMATOMEDINS)}

The 'somatomedin hypothesis' arose from the observation that cartilage from hypophysectomized rats was unresponsive to $\mathrm{GH}$ added in vitro, but incorporated sulphate in 
response to normal rat serum and serum from GH-treated hypophysectomized rats (Salmon \& Daughaday, 1957). It was suggested that there was a 'sulphation factor' or 'somatomedin' which mediated the effects of GH. The GH-dependency of this factor was confirmed by subsequent studies showing low levels of sulphation factor activity in hypopituitary patients, high levels in acromegalic patients, and raised levels in hypopituitary patients given human-GH (Hall, 1971).

The somatomedin peptides were first purified from human plasma and have a molecular weight of approximately 7500000 and show marked structural homology with pro-insulin (Rinderknecht \& Humbel, 1978 a,b). They possess a number of insulin-like properties, notably a potent hypoglycaemic effect, and, therefore, have been named insulin-like growth factors (IGF)'. In man, there are two distinct somatomedins; somatomedin-C or (IGF-1) and IGF-2. A recent consensus has suggested that the term 'somatomedin' should be used as a generic designation with the specific growth factors referred to as IGF-1 and IGF-2 (Daughaday et al. 1987). IGF-1 is highly GH-dependent, has potent mitogenic activity in vitro, and its serum levels generally reflect $\mathrm{GH}$ activity, being high in acromegaly and low in GH deficiency (Hall \& Sara, 1984).

The IGF, unlike most other peptide hormones, are associated in serum with specific binding proteins. The two major species of binding protein are the predominant GHdependent protein (IGFBP-3) of approximately 150000 molecular weight, and a GHindependent protein of approximately 30000 (IGFBP-1) (Letter, 1990). Whereas levels of IGFBP-3 show little, if any, diurnal variation, IGFBP-1 appears to be metabolically regulated. Serum levels of IGFBP-1 show a diurnal rhythm with an inverse relationship to insulin and may have a critical role in maintaining glucose homeostasis (Baxter \& Cowell, 1987; Yeoh \& Baxter, 1988). A rise in IGFBP-1, through increasing the bound fraction of IGF, could be protective against the hypoglycaemic, insulin-like effects of IGF-1, and inhibit the growth-promoting effects, when insulin levels and fuel substrate are low (Taylor et al. 1990).

There is considerable debate as to whether the somatomedins act in an endocrine, paracrine or autocrine fashion. The role of circulating IGF-1, which derives mainly from the liver, remains unclear, but as discussed below it may be important in GH feedback. Studies in which GH and IGF-1 have been infused into the hindlimb of rats have demonstrated a local growth-promoting effect which is abolished by antiserum to IGF-1 (Schlechter et al. 1986; Isaksson et al. 1987). These results are generally consistent with the 'somatomedin hypothesis' that the growth-promoting action of GH is mediated through IGF-1, but shift the emphasis away from circulating IGF-1 produced in the liver and towards locally generated IGF-1.

\section{GH FEEDBACK}

There is good evidence that GH modulates its own secretion, but whether by a direct or indirect effect remains unclear. The GH response to pharmacological stimuli such as insulin-induced hypoglycaemia and arginine, and to physiological stimuli such as sleep and exercise is attenuated by pretreatment with human GH (Abrams et al. 1971; Hagen et al. 1972; Mendelson et al. 1983). This inhibition of response to both pharmacological and physiological stimuli could be a direct action of $\mathrm{GH}$, or be mediated indirectly by $\mathrm{GH}$ induced IGF-1 production or by other metabolic factors under the influence of $\mathrm{GH}$, such as a rise in free fatty acid (FFA) levels. Both GH and IGF-1 may exert feedback at either the hypothalamic or pituitary level; at the hypothalamus, control of GH release could, in turn, be mediated either through altered GHRH or SMS secretion.

GH pretreatment blocks the response to GHRH, both when given acutely before a rise 
in serum IGF-1 can be generated (Ross et al. 1987a) and after prolonged treatment associated with a rise in IGF-1 levels (Nakamoto et al. 1986; Rosenthal et al. 1986). GH can therefore regulate its own secretion independently of circulating IGF-1, although the mechanism for this may require local generation of IGF-1 in the hypothalamus or pituitary. Circulating IGF-1 may offer a further regulatory influence on GH secretion. There is evidence in man to suggest that GH feedback occurs under hypothalamic control, through SMS, since pyridostigmine, an acetylcholinesterase inhibitor that reduces SMS release, blocks GH feedback (Ross et al. 1987 c). In addition, there is good evidence from both in vivo and in vitro studies in the rat that GH and IGF-1 induce release of hypothalamic SMS (Sheppard et al. 1978; Tannenbaum, 1980; Tannenbaum et al. 1983; Berelowitz et al. 1981) and that IGF-1 but not SMS will suppress pituitary GH mRNA (Namba et al. 1989). Receptors for IGF-1 and IGF-2 are widely distributed within the central nervous system of rats, particularly in the pituitary gland and the median eminence of the hypothalamus (Lesniak et al. 1988; Ocrant et al. 1989). Notably, reduced energy intake sufficient to lower plasma IGF-1 levels is associated with an increase in IGF-1 receptors in the median eminence (Bohannon et al. 1988).

In man, repetitive administration of GHRH at two-hourly intervals is accompanied by attenuation of the GH response, but with a continuous infusion of GHRH there is augmentation of the amplitude of endogenous GH secretory pulses (Shibasaki et al. 1985; Vance et al. 1985). The likely explanation for these findings is that the frequency of GH pulses is determined by variations in background SMS activity and the amplitude by a pulse of GHRH coincident with trough levels of SMS. The pulse of GH contributes in turn to inhibition of further GH release through the feedback loop, provoking an increase in SMS release. A further level of control is suggested by the observation that GHRH may itself exert feedback stimulation of SMS release (Lumpkin et al. 1985).

\section{THYROID AND STEROID HORMONES}

Thyroid hormones, glucocorticoids and sex steroids all influence GH secretion. Hypothyroidism in man is associated with decreased $\mathrm{GH}$ release on provocative testing and spontaneous nocturnal $\mathrm{GH}$ secretion shows a reduction of $\mathrm{GH}$ pulse amplitude in children with severe hypothyroidism, with recovery over 3-6 months after thyroxine replacement (Iwatsubo et al. 1967; Buchanan et al. 1988). Regulation of GH secretion has been more clearly defined in animal models or in vitro systems. The rat GH gene contains thyroid-and glucocorticoid hormone-responsive elements and these may independently promote increased GH synthesis (Gick \& Bancroft, 1987; Wight et al. 1987). Glucocorticoids may have net positive or negative influences on $\mathrm{GH}$ secretion according to whether the predominant effect is on hypothalamic SMS and GHRH release, or directly on the pituitary somatotroph (Nakagawa et al. 1987). Dexamethasone (a potent glucocorticoid) will ablate the inhibitory effect of IGF-1 on GH release by rat pituitary cells in vitro (Lamberts et al. 1989). In man, short-term steroid treatment augments $\mathrm{GH}$ release but long-term treatment suppresses GH release (Burguera et al. 1990).

Oestrogens are probably responsible for the differences in $\mathrm{GH}$ release between men and women, in particular with regard to the rise in GH secretion seen during puberty, and may account for the sexual dimorphism of GH secretion in other species (Conway et al. 1989). It is not clear whether the effects of androgens are mediated through oestrogens or act independently. Oestrogens, both endogenous and administered, are known to enhance basal and stimulated GH release. Women have higher basal levels of GH than men (Unger et al. 1965), especially during the high oestrogenic phase of the menstrual cycle (Frantz \& Rabkin, 1965), and oestrogen pretreatment of normal men increases both basal and 
stimulated GH secretion (Frantz \& Rabkin, 1965; Merimee et al. 1966). Androgens increase the $\mathrm{GH}$ response to provocative stimuli in prepubertal children (Laron et al. 1972), but have no effect on either the basal or stimulated GH secretion of adult women (Merimee et al. 1969, Merimee \& Fineberg, 1971). Ho et al. (1987) have demonstrated a close correlation between oestradiol levels and GH pulse amplitude. Oestradiol appeared to increase $\mathrm{GH}$ pulse amplitude and duration rather than frequency. Oestrogen pretreatment does not alter the GH response to exogenous GHRH, suggesting that its effects are to augment endogenous GHRH release (Ross et al. 1987 b).

\section{NEUROTRANSMITTERS AND GH RELEASE}

Neurons containing catecholamines, acetylcholine, the amino-acid neurotransmitter $\gamma$ aminobutyric acid (GABA), and the opioid peptides are found in the hypothalamus. There is a complex interaction between the various neurotransmitters and both SMS and GHRH, but as yet, which neurotransmitters have the most important role in physiological GH secretion remains unclear.

Studies with $\alpha$-adrenergic agonists and antagonists suggest that $\alpha-2$ adrenergic receptor stimulation is important in GH release stimulated by hypoglycaemia (Tatár \& Vigaš, 1984). The $\alpha-2$ agonist, clonidine, stimulates GH release in man and is used as a test of GH secretion (Lanes \& Hurtado, 1982). $\alpha-2$ adrenergic stimulation may cause GH release through increased GHRH secretion, as rats depleted in GHRH fail to respond to clonidine (Katakami et al. 1984). Propranolol, a $\beta$-adrenergic blocker, enhances the GH response to insulin-induced hypoglycaemia and GHRH in man, an effect that may be mediated through inhibition of SMS release (Chihara et al. 1985). Dopamine stimulates transient GH release in man and augments the GH response to GHRH (Bansal et al. 1981; Delitala et al. 1987).

The cholinergic nervous system is important in the regulation of $\mathrm{GH}$ secretion. Atropine and pirenzepine, both cholinergic muscarinic antagonists, block the $G H$ response to physiological stimuli of $\mathrm{GH}$ secretion such as sleep and the GH response to GHRH (Casanueva et al. 1984; Jordan et al. 1986; Massara et al. 1986; Peters et al. 1986; Delitala et al. 1987). Similarly, drugs which act by enhancing cholinergic tone, such as the acetylcholinesterase inhibitors, increase GH secretion and augment the GH response to GHRH (Leveston \& Cryer, 1980; Massara et al. 1986; Ross et al. 1987c). Acetylcholine inhibits SMS release from the rat hypothalamus (Richardson et al. 1980), while the effects of cholinergic manipulation on $\mathrm{GH}$ secretion in rats were abolished by depletion of hypothalamic SMS (Locatelli et al. 1986). Thus, findings in animals suggest that the effect of cholinergic manipulation on GH secretion is mediated through hypothalamic SMS secretion. However, in man the mechanism of action is less clear (Freeman et al. 1990).

Basal GH secretion is stimulated by GABA and by a number of GABA-ergic drugs such as muscimol, baclofen, and diazepam. In contrast, GABA is able to reduce the GH response to insulin-induced hypoglycaemia. A dualistic role of GABA on dopamine secretion and GH release has been suggested (Bercu \& Diamond, 1986). The opioid peptides also stimulate GH release, an effect blocked by low doses of naloxone (Stubbs et al. 1978; Grossman, 1983). The GH response to maximal doses of GHRH is augmented by the opioids, suggesting that they act independently of GHRH (Delitala et al. 1987).

The contribution of serotonin remains controversial as both stimulatory and inhibitory influences have been reported in man. The role of histamine is also difficult to establish because of the poor neuropharmacological specificity of its antagonists, which frequently also possess anti-cholinergic and anti-dopaminergic properties. Most evidence favours an inhibitory role for histamine on both basal and stimulated GH release (Netti et al. 1981). 
Glucose Insulin FFA GH IGF-1 Catabolism

\begin{tabular}{|c|c|c|c|c|c|c|}
\hline Fasting & $N$ & 1 & 4 & $\hat{\top}$ & & $\boldsymbol{\uparrow}$ \\
\hline Malnutrition & N & $\downarrow$ & $\hat{1}$ & $\uparrow$ & & $\bar{\varphi}$ \\
\hline Sepsis & 1 & 4 & $\uparrow$ & $\hat{1}$ & & $\hat{\uparrow}$ \\
\hline Diabetes mellitus & $\uparrow$ & $\downarrow$ & $\mathbf{N}$ & $\hat{\uparrow}$ & & $\hat{T}$ \\
\hline Obesity & $N$ & 4 & $\mathbf{N}$ & & $/ \uparrow$ & $\downarrow$ \\
\hline
\end{tabular}

Fig. 5. Metabolic effects on the growth hormone (GH) insulin-like growth factor (IGF) axis in varying nutritional states. FFA, free fatty acids: N. within normal limits.

\section{THE INFLUENCE OF NUTRITION ON GH SECRETION}

The nutritional state of subjects and patients has a profound effect on GH secretion and IGF-1 levels. As discussed below, metabolic factors, obesity, fasting, anorexia, diabetes mellitus, malnutrition and catabolic states interact with the GH-IGF axis, resulting in differing profiles of GH and IGF secretion (Fig. 5). Serum IGF-1 shows a close correlation with nitrogen balance in sick or malnourished patients and is a sensitive indicator of nutritional status (Clemmons et al. 1985; Minuto et al. 1989).

\section{METABOLIC FACTORS}

Several metabolic factors influence GH secretion, in particular glucose, insulin, FFA and amino acids.

Acute hypoglycaemia is a potent stimulus to $\mathrm{GH}$ secretion, and it is likely that GH normally functions as a counter-regulator of glucose levels through effects on glucose production, glucose utilization and lipolysis, although this role is not entirely clear (Davidson, 1987; De Feo et al. 1989). Insulin-induced hypoglycaemia is well established as a clinical test for evaluating the integrity of the hypothalamo-pituitary axis through provocation of GH relcase (Frasier, 1974).

In contrast, an acute rise in glucose after oral or intravenous administration to normal individuals will inhibit GH release and the GH response to GHRH (Davies et al. 1984; Sharp et al. 1984; Garrel et al. 1989). Enhanced cholinergic tone, using pyridostigmine, will counteract this suppressive effect of glucose on GH release probably through effects on SMS secretion (Balzano et al. 1989). However, neither acute nor sustained hyperglycaemia has a consistent suppressive effect on GH secretion in the rat (Imaki et al. 1986; King et al. 1986).

In addition to the indirect stimulatory effect of insulin through hypoglycaemia on $\mathrm{GH}$ release, it has a direct suppressive effect on $\mathrm{GH}$ synthesis by pituitary cells in vitro through inhibition of GH gene transcription (Yamashita \& Melmed, 1986), suggesting a mechanism for increased GH production during periods of reduced nutrition and the reverse with hyperinsulinaemia and obesity (Ahmad et al. 1989). Insulin may, however, exert both 
positive and negative effects on GH gene expression according to the presence of other regulatory factors (c.g. dexamethasone and triiodothyronine) (Isaacs et al. 1987).

The fatty acids will, like glucose, inhibit GH release and the GH response to GHRH (Imaki et al. 1985, 1986; Sartin et al. 1988), and there is evidence in vitro that the effect of FFA is exerted at the pituitary level (Casanueva et al. 1987). It has been suggested that GH feedback is in part mediated by FFA (Rosenbaum et al. 1989), but this seems unlikely as FFA levels rise during a prolonged fast in association with augmented $\mathrm{GH}$ release (Ho et al. 1988).

Intravenous infusion of essential amino acids, the fundamental requirements for protein metabolism, will stimulate GH release in humans and non-primate species (Knopf et al. 1965; Davis, 1972). Arginine, histidine and lysine are particularly potent. This may explain the post-prandial rise in plasma GH after a protein meal (Sukkar et al. 1967) and has formed the basis of a standard provocation test for GH secretion (Merimee et al. 1965, 1969). The mechanism whereby GH release is stimulated has not been studied for many amino acids, but arginine appears to act via the hypothalamus; sex-steroid status will influence the response to arginine (Merimee et al. 1966), arginine pretreatment will enhance GHRH-stimulated GH release, probably by suppression of endogenous SMS (Alba-Roth et al. 1988), and antimuscarinic agents such as atropine suppress arginine-induced GH secretion (Casanueva et al. 1984). Obesity and high plasma levels of phenylalanine in children with phenylketonuria have been reported to impair the $\mathrm{GH}$ response to arginine infusion (El-Khodary et al. 1971; Rosskamp et al. 1987 c).

\section{OBESITY}

Obese subjects show attenuated GH responses to most stimuli including insulin-induced hypoglycaemia and GHRH (Williams et al. 1984; Kopelman et al. 1985). Despite this, obese children tend to grow at an above-average rate. Circulating IGF-1 levels are higher in obese patients and have been reported to show a negative correlation with the $\mathrm{GH}$ response to GHRH (Loche et al. 1987), although not all groups have found this relationship (Davies et al. 1985 a; Rosskamp et al. 1987 b). The reduced response to GHRH returns to normal after weight loss and it is likely that it is a consequence rather than a cause of obesity (Williams et al. 1984; Csizmadi et al. 1989). The obese rat, which is hyperinsulinaemic, shows low pituitary GH mRNA levels (Ahmad et al. 1989). The suppressed GH secretion in obesity may, therefore, be a consequence of the hyperinsulinaemia or increased IGF-1 levels sometimes seen in this state.

Since GH has nitrogen-preserving and lipolytic actions (Davidson, 1987), it may be of benefit in obese patients attempting to lose weight (Thorner \& Vance, 1988). Short-term $\mathrm{GH}$ administration was effective in decreasing the loss of lean body mass in individuals on restricted dietary intake, but fat loss was not accelerated (Clemmons et al. 1987). The same group have also demonstrated that the dietary carbohydrate content determines responsiveness to $\mathrm{GH}$ in obese patients on an energy-restricted diet (Snyder et al. 1989). The higher the carbohydrate content of the restricted diet the lower the $\mathrm{N}$ excretion of the patients. Interestingly in this second study patients showed increased body fat loss on GH treatment.

\section{FASTING AND ANOREXIA}

Fasted normal subjects have marked changes in their pattern of $\mathrm{GH}$ release. In a comprehensive study Ho et al. (1988) demonstrated that a $5 \mathrm{~d}$ fast in normal adult males resulted in increased $\mathrm{GH}$ pulse frequency, amplitude, and interpulse GH levels. The increase in pulse frequency and amplitude was evident on the first day of the fast. Serum 
IGF-1 levels declined gradually over the $5 \mathrm{~d}$. The $\mathrm{GH}$ response to $\mathrm{GHRH}$ was the same at the end of the fast as the beginning, suggesting that the changes in GH secretion were not due to changes in the pituitary sensitivity to GHRH. Similar elevation of GH secretion on food restriction has been observed in most species studied (Atinmo et al. 1978; Driver \& Forbes, 1981 ; Scanes et al. 1981 ; Breier et al. 1988; Cella et al. 1989; Foster et al. 1989). A notable exception is the rat, in which GH levels fell on fasting, in response to increased SMS release, and catch-up growth on refeeding was associated with enhanced $\mathrm{GH}$ secretion through increased GH pulse amplitude (Tannenbaum et al. 1979; Mosier et al. 1985).

It is well recognized that fasting and malnutrition are associated with low IGF-1 levels. From refeeding studies in both man and the rat it appears that both energy and protein are required for the normal production of IGF-1 (Phillips \& Unterman, 1984). Anorexia nervosa is associated with elevated basal GH levels similar to that seen in fasted subjects, and again the GH response to GHRH is the same as control subjects (Casanueva et al. 1987; De Marinis et al. 1988). The findings in fasting and anorexia are the converse of obesity; greater GH secretion and low IGF-1 levels. Possibly the lack of IGF-1 feedback results in greater $\mathrm{GH}$ release.

\section{DIABETES}

In contrast to normal subjects, the hyperglycaemia of diabetes mellitus and sick patients with insulin resistance is associated with augmented rather than depressed GH secretion (Asplin et al. 1989; Ross et al. 1990). Patients with insulin-dependent diabetes have greater amplitude and frequency of $\mathrm{GH}$ pulses and higher interpulse $\mathrm{GH}$ levels compared with controls (Asplin et al. 1989), yet they have lower IGF-1 levels than controls. The GH response to GHRH in diabetes has been reported to be greater than, or similar to, that of controls (Press et al. 1984). A 'normal' response to GHRH, however, would be inappropriate in the presence of hyperglycaemia. The abnormality of $\mathrm{GH}$ secretion seen in diabetics appears to correlate inversely with their diabetic control. In diabetics and children with kwashiorkor, oral glucose does not provoke the usual suppression of GH secretion (Press et al. 1984; Pimstone et al. 1967). Thus, the pattern of GH secretion seen in diabetics is similar to that seen in fasted subjects and may well reflect the consequences of intracellular starvation under conditions of insulin deficiency.

\section{MALNUTRITION AND CATABOLIC STATES}

Early observations on $\mathrm{GH}$ secretion in malnourished states were mainly in children with protein and/or energy deficiency of kwashiorkor and marasmus (Becker, 1983). Plasma GH levels were high in the presence of low insulin, albumin and amino acid levels and returned to normal within days of refeeding with protein (Pimstone et al. 1966, 1968). Oral feeding of such children with essential amino acids, but not an intravenous glucose load, provoked a fall in GH within just 30 min (Milner, $1971 a, b$ ), and the acute rise in $\mathrm{GH}$ after arginine infusion was obtunded (Graham et al. 1969; Soliman et al. 1986). This reversal of the normal pattern of $\mathrm{GH}$ response to metabolic cues was clearly an adaptive phenomenon in nutritional deprivation, although the mechanism and purpose were unclear.

A paradox existed, as depressed amino acid levels were associated with high $\mathrm{GH}$ levels when the supply of substrate for growth was deficient. Infusions of amino acids singly or in combination failed to identify an individual amino acid capable of reversing these changes in GH secretion and a similar pattern of GH release could not be reproduced by manipulation of, in particular, the branched-chain amino acids released during starvation and gluconeogenesis. 


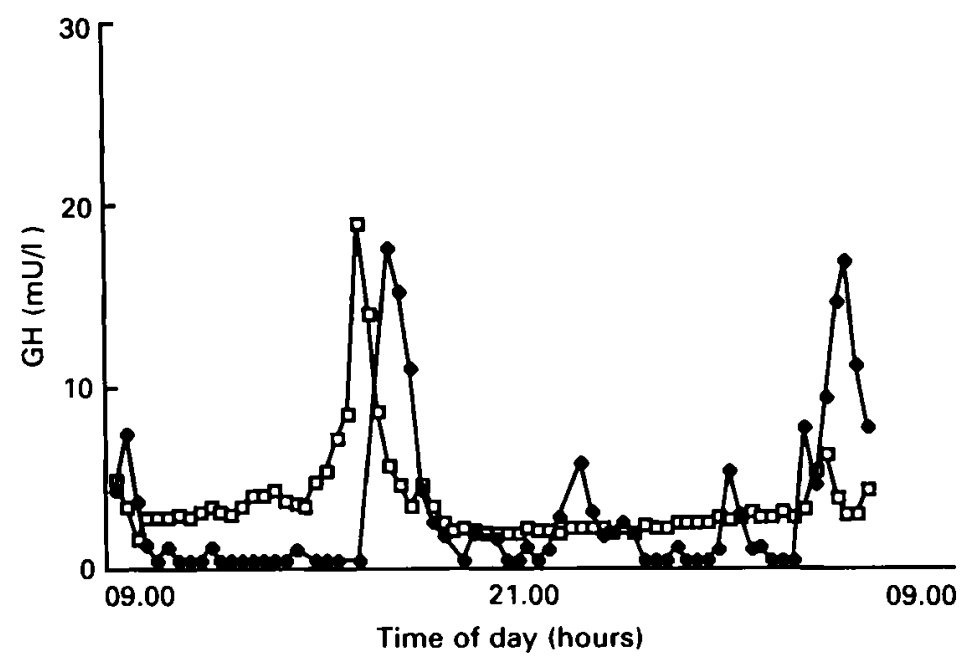

Fig. 6. $24 \mathrm{~h}$ growth hormone (GH) profile ( $20 \mathrm{~min}$ sampling) in a 53 -year-old patient suffering from sepsis and catabolism following bowel surgery $(\square)$, compared with an age- and sex-matched control $(\bullet)$. Baseline GH levels are consistently elevated in the patient, failing to return to undetectable levels between pulses (R. J. M. Ross \& C. R. Buchanan, unpublished results).

Realization that sulphation (somatomedin, IGF) activity was reduced in protein malnutrition helped focus attention on how GH might be diverted from its growthpromoting effects to acquire a more important role in the regulation of available metabolic fuels (Grant et al. 1973; Shapiro et al. 1978; Phillips, 1986). This response is not restricted to the malnourished child, but occurs similarly in fasted healthy or obese adults (see p. 10), and particularly in undernourished critically ill patients (Phillips \& Unterman, 1984; Freeman et al. 1989; R. J. M. Ross, unpublished results).

Critically ill, septic patients show an increase in interpulse GH levels compared with fasted controls, yet have similar GH pulse frequency and mean GH levels throughout 24 h (Freeman et al. 1989) (Fig. 6). There has been no detailed analysis of the pattern of GH secretion in protein-energy malnourished children, with single basal GH levels having formed the basis of most published studies. The elevated circulating levels of $\mathrm{GH}$ in protein-energy malnutrition have, however, been shown to result from enhanced secretion, rather than impaired clearance, by demonstration of a normal GH disappearance time during SMS infusion (Pimstone et al. 1975).

Overall, the findings suggest that catabolic states and malnutrition are associated with low serum IGF-1 levels and enhancement of GH secretion. This occurs through an increase in interpulse GH levels and possibly in GH pulse amplitude rather than increased pulse frequency. An explanation may be that circulating or centrally generated IGF-1 is important in GH feedback and that low levels of IGF-1 lead to decreased hypothalamic SMS release and thus an increase in basal GH release. The low IGF-1 levels suggest these patients have a 'GH-resistant' state.

In normal or diabetic rats, this effect of protein restriction appears to be achieved through a post-receptor defect in the $\mathrm{GH}$-tissue axis since $\mathrm{GH}$ binding to liver is normal but IGF-1 production reduced (Maes et al. 1986; Maiter et al. 1989). Insulin deficiency, however, may additionally result in reduced GH binding to its liver receptors (Maiter $e t$ al. 1989). 
With increased understanding of the pathophysiology of malnutrition and catabolic states, it is hoped that advances may be achieved in the clinical management of such disorders through manipulation of one or more components of the GH-IGF axis. It remains to be seen whether GH or IGF-1 has a therapeutic role to improve the nutritional state of sick patients. There is already good evidence that treatment with GH can improve $\mathrm{N}$ balance in fasted normal subjects and patients following gastrointestinal surgery and thus potentially accelerate recovery (Manson \& Wilmore, 1986; Ward et al. 1987; Ziegler et al. 1988). In these patients metabolic regulatory mechanisms are so adapted that the GH levels necessary for such effects are only obtained with relatively 'high' doses of exogenous GH. A recent exciting observation is that fasted mice treated with IGF-1 showed less weight loss than untreated mice (O'Sullivan et al. 1989).

In the malnourished patient the altered relationship between GH and IGF-1 may represent a protective response. In the fasted state, hypoglycaemia is a persistent danger and appropriate substrates are required for the liver to synthesize essential proteins. The fall in IGF-1 may be an essential permissive event to allow muscle catabolism to yield metabolic fuels and avoid the hazards of hypoglycaemia. Similarly, the accompanying rise in $\mathrm{GH}$ levels promotes insulin resistance and lipolysis, both protective metabolic changes during acute and prolonged dietary restriction.

Considerable advances have been made in recent years in our understanding of the factors regulating GH secretion, and its effects on growth and intermediary metabolism. The recent availability of recombinant $\mathrm{GH}$ and IGF, characterization of the GH receptor (Waters et al. 1990) and the GH- and IGF-binding proteins will greatly enhance our knowledge of this field and may provide new therapies for some nutritional disorders.

\section{REFERENCES}

Abrams, R. L., Grumbach, M. M. \& Kaplan, S. L. (1971). The effect of administration of human growth hormone on plasma growth hormone, cortisol, glucose, and free fatty acid response to insulin: evidence for growth hormone autoregulation in man. Journal of Clinical Investigation 50, 940-950.

Adlard, P., Buzi, F., Jones, J., Stanhope, R. \& Preece, M. A. (1987). Physiological growth hormone secretion during slow-wave sleep in short prepubertal children. Clinical Endocrinology 27, 355-361

Ahmad, I., Steggles, A. W., Carrillo, A. J. \& Finkelstein, J. A. (1989). Obesity-related and sex-related alterations in growth hormone messenger RNA levels. Molecular and Cellular Endocrinology 65, 103-109.

Alba-Roth. J. Müller, O. A., Schopohl, J. \& von Werder, K. (1988). Arginine stimulates growth hormone secretion by suppressing endogenous somatostatin secretion. Journal of Clinical Endocrinology and Metabolism 67, $1186 \cdot 1189$

Argente, J., Evain Brion, D., Donnadieu, M., Garnier, P., Vaudry, H. \& Job, J. C. (1987). Impaired response of growth hormone-releasing hormone (GHRH) measured in plasma after L-dopa stimulation in patients with idiopathic delayed puberty. Acta Paediatrica Scandinavica 76, 266-270.

Arimura, A., Smith, W. D. \& Schally, A. V. (1976). Blockade of the stress-induced decrease in blood GH by antisomatostatin serum in rats. Endocrinology $98,540-543$.

Asplin, C. M., Faria, A. C. S., Carlsen, E. C., Vaccaro, V. A., Carr, R. E., Iranmaesh, A., Lee, M. M., Veldhuis, J. D. \& Evans, W. S. (1989). Alterations in the pulsatile mode of growth hormone release in men and women with insulin-dependent diabetes mellitus. Journal of Clinical Endocrinology and Metabolism 69, 239245.

Atinmo, T., Baldijao, C., Houpt, K. A., Pond, W. G. \& Barnes, R. H. (1978). Plasma levels of growth hormone and insulin in protein malnourished $v s$ normal growing pigs in response to arginine or glucose infusion. Journal of Animal Science 46, 409-416.

Balzano, S., Loche, S., Murtas, M. L., Fanni, T., Sica, V., Pintor, C. \& Martino, E. (1989). Potentiation of cholinergic tone counteracts the suppressive effect of oral glucose administration on the GH response to GHRH in man. Hormone and Metabolic Research 21, 52--53.

Bansal, S. A., Lee, L. A. \& Woolf, P. D. (1981). Dopaminergic stimulation and inhibition of growth hormone secretion in normal man: studies of the pharmacologic specificity. Journal of Clinical Endocrinology and Metabolism 53, 1273-1277.

Barinaga, M., Bilezikjian, L. M., Vale, W. W., Rosenfeld, M. G. \& Evans, R. M. (1985). Independent effects of growth hormone releasing factor on growth hormone release and gene transcription. Nature 314, $279-281$. 
Baxter, R. C. \& Cowell, C. T. (1987). Diurnal rhythm of growth hormone-independent binding protein for insulin-like growth factors in human plasma. Journal of Clinical Endocrinology and Metabolism 65, 432440.

Becker. D. J. (1983). The endocrine responses to protein calorie malnutrition. Annual Review of Nutrition 3 , 187212.

Bercu, B. B. \& Diamond, F. B. (1986). Growth hormone neurosecretory dysfunction. In Clinics in Endocrinology and Melabolism, vol. 15, pp. 537590 [M. O. Savage and R. A. Randall, editors]. London: W. B. Saunders.

Berelowitz, M., Szabo, M., Frohman, L. A., Firestone, S. \& Chu, L. (1981). Somatomedin-C mediates growth hormone negative feedback by effects on both the hypothalamus and the pituitary. Science 212, 1279-1281.

Bloch, B., Brazeau, P., Ling, N., Böhlen, P., Esch, F., Wehrenberg, W. B., Benoit, R., Bloom, F. \& Guillemin, R. (1983). Immunohistochemical detection of growth hormone-releasing factor in brain. Nature 301, $607-608$.

Bohannon, N. J., Corp, E. S., Wilcox, B. J., Figlewicz, D. P., Dorsa, D. M. \& Baskin, D. G. (1988). Characterization of insulin-like growth factor 1 receptors in the median eminence of the brain and their modulation by food restriction. Endocrinology 122. 19401947.

Born, J., Muth, S. \& Fehm, H. L. (1988). The significance of sleep onset and slow wave sleep for nocturnal release of growth hormone $(\mathrm{GH})$ and cortisol. Psychoneuroendocrinology 13, 233-243.

Brazeau, P., Vale, W., Burgus, R., Ling, N., Butcher, M., Rivier, J. \& Guillemin, R. (1973). Hypothalamic polypeptide that inhibits the secretion of immunoreactive pituitary growth hormone. Science 179, $77-79$.

Breier, B. H., Gluckman, P. D. \& Bass, J. J. (1988). Influence of nutritional status and oestradiol-17 $\beta$ on plasma growth hormone, insulin-like growth factors- 1 and -2 and the response to exogenous growth hormone in young steers. Journal of Endocrinology 118, 243-250.

Buchanan, C. R., Stanhope, R., Adlard, P., Jones, J., Grant, D. B. \& Preece, M. A. (1988). Gonadotrophin, growth hormone and prolactin secretion in children with primary hypothyroidism. Clinical Endocrinology 29, 427436.

Burguera, B., Muruais, C., Peñalva, A., Dieguez, C. \& Casanueva, F. F. (1990). Dual and selective actions of glucocorticoids upon basal and stimulated growth hormone release in man. Neuroendocrinology 51, 51. 58.

Casanueva. F. F. Villanueva, L., Cabranes, J. A., Cabezas-Cerrato, J. \& Fernandez-Cruz, A. (1984). Cholinergic mediation of growth hormone secretion elicited by arginine, clonidine, and physical exercise in man. Journal of Clinicul Endocrinology and Metabolism 59, 526530.

Casanueva, F. F., Villanueva, L., Dieguez, C., Diaz, Y., Cabranes, J. A., Szoke, B., Scanlon, M. F., Schally, A. V. \& Fernandez-Cruz, A. (1987). Free fatty acids block growth hormone (GH) releasing hormone-stimulated GII secretion in man directly at the pituitary. Journal of Clinical Endocrinology and Metabolism 65, 634-642.

Cella, S. G., Moiraghi, V., Minuto, F., Barreca. A., Cocchi, D., De Gennaro Colonna, V., Reina, G. \& Muller, E. E. (1989). Prolonged fasting or clonidine can restore the defective growth hormone secretion in old dogs. Acta Endocrinologica 121, 177184.

Chihara, K., Kodama, H., Kaji, H., Kita, T., Kashio, Y., Okimura, Y., Abe, H. \& Fujita, T. (1985). Augmentation by propranolol of growth hormone-releasing hormone-( 144$)-\mathrm{NH} 2$-induced growth hormone release in normal short and normal children. Journal of Clinical Endocrinology and Metabolism 61, $229-233$.

Clemmons, D. R., Snyder, D. K., Williams, R. \& Underwood, L. E. (1987). Growth hormone administration conserves lean body mass during dietary restriction in obese subjects. Journal of Clinical Endocrinology and Melabolism 64, 878-883.

Clemmons, D. R., Underwood, L. E., Dickerson, R. N., Brown, R. O., Hak, L. J.. MacPhee, R. D. \& Heizer, W. D. (1985). Use of plasma somatomedin-C/insulin-like growth factor 1 measurements to monitor the response to nutritional repletion in malnourished patients. American Journal of Clinical Nutrition 41, 191198.

Conway, S., Moherek, R., Mauceri, H. \& Richardson, L. (1989). Sexually dimorphic characteristics of clonidineinduced growth hormone release and autofeedback. Journal of Clinical Endocrinology and Metabolism 125, 2475-2485.

Csizmadi, I., Brazeau, P. \& Serri, O. (1989). Effect of dietary restriction and repeated growth hormone-releasing factor injections on growth hormone response to growth hormone-releasing factor in obese subjects. Metabolism 38, 1016-1021.

Daughaday, W. H., Hall, K., Salmon, W. D., Van den Brande, J. L. \& Van Wyk, J. J. (1987). On the nomenclature of the somatomedins and insulin-like growth factors. Journal of Clinical Endocrinology and Metaholism 65, 1075-1076.

Davidson, M. B. (1987). Effect of growth hormone on carbohydrate and lipid metabolism. Endocrine Reviens 8 , $115-131$.

Davies, R. R., Turner, S. J., Cook, D., Alberti, K. G. M. M. \& Johnston, D. G. (1985a). The response of obese subjects to continuous infusion of human pancreatic growth hormone-releasing factor 1-44. Clinical Endocrinology 23, 521525.

Davies, R. R., Turner, S. \& Johnston, D. G. (1984). Oral glucose inhibits growth hormone secretion induced by human pancreatic growth hormone releasing factor $1-44$ in normal man. Clinical Endocrinology 21, 477-481.

Davies, R. R. Turner, S. J., Orskov, H. \& Johnston, D. G. (1985b). The interaction of human pancreatic growth hormone releasing factor 144 with somatostatin in vivo in normal man. Clinical Endocrinology 23, 271276.

Davis, S. L. (1972). Plasma levels of prolactin, growth hormone and insulin in sheep following the infusion of arginine, leucine and phenylalanine. Endocrinology $91,549555$. 
De Feo, P., Perriello, G., Torlone, E., Ventura, M. M., Santeusanio, F., Brunetti, P., Gerich, J. E. \& Bolli, G. B. (1989). Demonstration of a role for growth hormone in glucose counter regulation. American Journal of Physiology 256, E835-E843.

Delitala, G., Palermo, M., Ross, R., Coy, D., Besser, G. M. \& Grossman, A. (1987). Dopaminergic and cholinergic influences on the growth hormone response to growth hormone-releasing hormone in man. Neuroendocrinology 45, 243-247.

De Marinis, L., Folli. G., D’Amico, C., Mancini, A., Sambo, P., Tofani, A., Oradei, A. \& Barbino, A. (1988). Differential effects of feeding on the ultradian variation of the growth hormone $(\mathrm{GH})$ response to $\mathrm{GH}$-releasing hormone in normal subjects and patients with obesity and anorexia nervosa. Journal of Clinical Endocrinology and Metabolism 66, 598-604.

Driver, P. M. \& Forbes, J. M. (1981). Episodic growth hormone secretion in sheep in relation to time of feeding spontaneous meals and short term fasting. Journal of Physiology 317, 413424.

El-Khodary, A. Z., Ball, M. F., Stein, B. \& Canary, J. J. (1971). Effect of weight loss on the growth hormone response to arginine infusion in obesity. Journal of Clinical Endocrinology and Metabolism 32, 4251.

Finkelstein, J. W., Roffwarg, H. P., Boyar, R. M., Kream, J. \& Hellman, L. (1972). Age-related change in the twenty-four-hour spontaneous secretion of growth hormone. Journal of Clinical Endocrinology and Metabolism 35, 665-671

Foster, D. L., Fbling, F. J. P., Micka, A. F., Vannerson, L. A., Bucholz, D. C., Wood, R. I., Suttie, J. M. \& Fenner, D. E. (1989). Metabolic interfaces between growth and reproduction. I. Nutritional modulation of gonadotrophin, prolactin, and growth hormone secretion in the growth-limited female lamb. Endocrinology 125, 342350 .

Frantz, A. G. \& Rabkin. M. T. (1965). Effects of estrogen and sex difference on secretion of human growth hormone. Journal of Clinical Endocrinology and Metabolism 25, 14701480.

Frasier, S. D. (1974). A review of growth hormone stimulation tests in children. Pediatrics 53, 929-937.

Freeman, E., Buchanan, C. R., Jones, J., Preece, M. A. \& Ross, R. J. M. (1989). Critically ill patients have high basal GH levels with low serum $1 G F-1$, but similar mean 24 hour $\mathrm{GH}$ concentration compared to controls. Journal of Endocrinology Suppl. 123, 125.

Freeman, E., Touzel, R., Grossman, A. Besser, G. \& Ross, R. J. M. (1990). Pyridostigmine an acetylcholinesterase inhibitor stimulates growth hormone release but has no effect on basal thyrotrophin or adrenocorticotrophin levels or the thyrotrophin response to thyrotrophin releasing hormone. Journal of Neuroendocrinology' 2 , $429-432$

Frohman, L. A. \& Jansson, J. O. (1986). Growth hormone-releasing hormone. Endocrine Reviews 7, $223-253$.

Garrel, D. R., Bajard, L., Harfouche, M. \& Tourniaire, J. (1989). Effect of sustained hyperglycemia on GHRH induced GH secretion in man. Diabète el Métabolisme 15, 251-254.

Gelato, M. C., Pescovitz, O., Cassorla, F., Loriaux, D. L. \& Merriam, G. R. (1983). Effects of a growth hormone releasing factor in man. Journal of Clinical Endocrinology and Metabolism 57, 674-676.

Gick, G. G. \& Bancroft, C. (1987). Glucocorticoid stimulation of growth hormone messenger ribonucleic acid levels in $\mathbf{G H}_{3}$ cells is inhibited by calcium but not by somatostatin. Endocrinology 120, 19861990.

Graham, G. G.. Cordano, A., Blizzard, R. M. \& Cheek, D. B. (1969). Infantile malnutrition : changes in body composition during rehabilitation. Pediatric Research 3, 579589.

Grant, D. B., Hambley, J., Becker, D. \& Pimstone, B. L. (1973). Reduced sulphation factor in undernourished children. Archives of Disease in Childhood 48, 596-600.

Grossman, A. (1983). Brain opiates and neuroendocrine function. Journal of Clinical Endocrinology and Melabolism 12, 725746 .

Grossman, A., Savage, M. O., Wass, J. A. H., Lytras, N., Sueiras-Diaz, J., Coy, D. H. \& Besser, G. M. (1983). Growth hormone-releasing factor in growth hormone deficiency: demonstration of a hypothalamic defect in growth hormone release. Lancet ii, 137138.

Guillemin, R., Brazeau, P., Bohlen, P., Esch, F., Ling, N. \& Wehrenberg. W. B. (1982). Growth hormonercleasing factor from a human pancreatic tumor that caused acromegaly. Science 218, 585-587.

Hagen, T. C., Lawrence, A. M. \& Kirsteins, L. (1972). Autoregulation of growth hormone secretion in normal subjects. Metabolism 21, 603610.

Hall, K. (1971). Effect of intravenous administration of human growth hormone on sulphation factor activity in serum of hypopituitary subjects. Acta Endocrinologica 66, 491-497.

Hall, K. \& Sara, V. R. (1984). Somatomedin levels in childhood, adolescence and adult life. Journal of Clinical Endocrinology and Metabolism 13, 91-112.

Hammer, R. E., Brinster, R. L., Rosenfeld, M. G., Evans, R. M. \& Mayo, K. E. (1985). Expression of human growth hormone-releasing factor in transgenic mice results in increased somatic growth. Nature 315, 413-416.

Ho, K. Y., Evans, W. S., Blizzard, R. M., Veldhuis, J. D., Merriam, G. R., Samojlik, E., Furlanetto, R., Rogol, A. D., Kaiser, D. L. \& Thorner, M. O. (1987). Effects of sex and age on the 24-hour profile of growth hormone secretion in man: importance of endogenous estradiol concentration. Journal of Clinical Endocrinology and Melabolism 64, 5158.

Ho, K. Y., Veldhuis, J. D., Johnson, M. L., Furlanetto, R., Evans, W. S., Alberti, K. G. M. M. \& Thorner, 
M. O. (1988). Fasting enhances growth hormone secretion and amplifies the complex rhythms of growth hormone secretion in man. Journal of Clinical Investigation 81, 968-975.

Imaki, T., Shibasaki, T., Masuda, A., Hotta, M., Yamauchi, N., Demura, H., Shizume, K., Wakabayashi, I. \& Ling, N. (1986). The effect of glucose and free fatty acids on growth hormone (GH)-releasing factor-mediated GH secretion in rats. Endocrinology 118, 2390-2394.

Imaki, T., Shibasaki. T., Shizume. K., Masuda, A., Hotta, M., Kiyosawa, Y., Jibiki, K., Demura, H., Tsushima, T. \& Ling, N. (1985) The effect of free fatty acids on growth hormone (GH)-releasing hormone-mediated GH secretion in primary hypothyroidism before and after treatment. Journal of Clinical Endocrinology and Metabolism 60, 290-293.

Isaacs, R. E., Gardner, D. G. \& Baxter, J. D. (1987). Insulin regulation of rat growth hormone gene expression. Endocrinology 120, 2022-2028.

Isaksson, O. G. P., Lindahl, A., Nilsson, A. \& Isgaard, J. (1987). Mechanism of the stimulatory effect of growth hormone on longitudinal bone growth. Endocrine Reviews 8, 426-438.

Iwatsubo, H., Omori, K., Okada, Y., Fukuchi, M., Miyai, K., Abe, H. \& Kumahara, Y. (1967). Human growth hormone secretion in primary hypothyroidism before and after treatment. Journal of Clinical Endocrinology and Melabolism 27, 1751-1754

Jordan, V., Dieguez, C., Lafaffian, I., Rodriguez-Arnao, M. D., Gomez-Pan, A., Hall, R. \& Scanlon, M. F. (1986). Influence of dopaminergic adrenergic and cholinergic blockade and TRH administration on GH responses to GRF I 29. Clinical Endocrinology 24, $291-298$.

Katakami, H., Kato, Y., Matsushita, N. \& Imura, H. (1984). Effects of neonatal treatment with monosodium glutamate on growth hormone release induced by clonidine and prostaglandin $\mathrm{El}$ in conscious male rats. Neuroendocrinology 38, 15.

King, R. A., Smith, R. M. \& Willoughby, J. O. (1986). Effects of sustained hyperglycemia on growth hormone secretion in free-moving rats. Hormone and Metabolic Research 18, 510-511.

Knopf, R. F., Conn, J. W., Fajans, S. S., Floyd, J. C., Guntsche, E. M. \& Rull, J. A. (1965). Plasma growth hormone response to intravenous administration of amino acids. Journal of Clinical Endocrinology and Metabolism 25, 11401144.

Kopelman, P. G., Noonan, K., Goulton, R. \& Forrest, A. J. (1985). Impaired growth hormone response to growth hormone releasing factor and insulin-hypoglycaemia in obesity. Clinical Endocrinology 23, 87-94.

Krulich, L., Dhariwal, A.P.S. \& McCann, S. M. (1968). Stimulatory and inhibitory effects of purified hypothalamic extracts on growth hormone release from rat pituitary in vitro. Endocrinology 83, $783-790$.

Lamberts, S. W. J., den Holder, F. \& Hofland, L. J. (1989). The interrelationship between the effects of insulinlike growth factor I and somatostatin on growth hormone secretion by normal rat pituitary cells: the role of glucocorticoids. Endocrinology 124, $905-911$.

Lanes, R. \& Hurtado, E. (1982). Oral clonidine - an effective growth hormone-releasing hormone in healthy individuals. Journal of Clinical Endocrinology and Metabolism 65, $535-540$.

Laron, Z., Hochman, I. H. \& Keret, R. (1972). The effect of methandrostenolone on pituitary growth hormone secretion in prepubertal children. Clinical Endocrinology 1, 91-97.

Lesniak, M. A., Hill, J. M., Kiess, W., Rojeski, M., Pert, C. B. \& Roth, J. (1988). Receptors for insulin-like growth factors I and II: autoradiographic localization in rat brain and comparison to receptors for insulin. Endocrinology 123, 2089-2099.

Letter (1990). Report on the nomenclature of the IGF binding proteins. Journal of Clinical Endocrinology and Metabolism 70, 817--818.

Leveston, S. A. \& Cryer, P. E. (1980). Fndogenous cholinergic modulation of growth-hormone secretion in normal and acromegalic humans. Metabolism 29, 703-706.

Ling, N., Baird, A., Wehrenberg, W. B., Ueno, N., Munegumi, T., Chiang, T.-C., Regno, M. \& Brazeau, P. (1984). Synthesis and in vitro bioactivity of human growth hormone-releasing factor analogs substituted at position-1. Biochemical and Biophysical Research Communications 122, 304-310.

Locatelli, V., Torsello, A., Redaelli, M., Ghigo, E., Massara, F. \& Müller, E. E. (1986). Cholinergic agonist and antagonist drugs modulate the growth hormone response to growth hormone-releasing hormone in the rat: evidence for mediation by somatostatin. Journal of Endocrinology 111, 271278.

Loche, S., Cappa, M., Borrelli, P., Faedda, A., Crinò, A., Cella, S. G., Corda, R., Müller, E. E. \& Pintor, C. (1987). Reduced growth hormone response to growth hormone-releasing hormone in children with simple obesity: evidence for somatomedin-C mediated inhibition. Clinical Endocrinology 27, 145-153.

Lumpkin, M. D., Samson, W. K. \& McCann, S. M. (1985). Effects of intraventricular growth hormone-releasing factor on growth hormone release: further evidence for ultrashort loop feedback. Endocrinology 116, $2070-2074$.

Maes, M.. Underwood, L. E. \& Ketelslegers, J.-M. (1986). Low serum somatomedin-C in insulin-dependent diabetes: evidence for a postreceptor mechanism. Endocrinology 118, 377-382.

Maiter, D., Fliesen, T., Underwood, L. E., Maes, M., Gerard, G., Davenport, M. L. \& Ketelslegers, J. M. (1989). Dietary protein restriction decreases insulin like growth factor 1 , independent of insulin and liver growth hormone binding. Endocrinology 124, 2604-2611. 
Manson, J. M. \& Wilmore, D. W. (1986). Positive nitrogen balance with human growth hormone and hypocaloric intravenous feeding. Surgery 100, 188-197.

Martha, P. M., Rogol, A. D., Veldhuis, J. D., Kerrigan, J. R., Goodman, D. W. \& Blizzard, R. M. (1989). Alterations in the pulsatile properties of circulating growth hormone concentrations during puberty in boys. Journal of Clinical Endocrinology and Metabolism 69, 563-570.

Martin. J. B. (1976). Brain regulation of growth hormone secretion. In Frontiers in Neuroendocrinology, vol. 4, pp. 129-169 [L. Martini and W. F. Ganong, editors]. New York: Raven Press.

Massara, F., Ghigo, E., Demislis, K., Tangolo, D., Mazza, E., Locatelli, V., Müller, E., Molinatti, G.-M. \& Camanni, F. (1986). Cholinergic involvement in the growth hormone releasing hormone-induced growth hormone release: studies in normal and acromegalic subjects. Neuroendocrinology 43, 670 675.

Mayo, K. E., Cerelli, G. M., Lebo, R. V., Bruce, B. D., Rosenfeld, M. G. \& Evans, R. M. (1985). Gene encoding human growth hormone-releasing factor precursor: structure, sequence, and chromosomal assignment. Proceedings of the National Academy of Sciences, USA 82, 63-68.

Mendelson, W. B., Jacobs, L. S. \& Gillin, J. C. (1983). Negative feedback suppression of sleep-related growth hormone secretion. Journal of Clinical Endocrinology and Melabolism 56, 486-488.

Merimee, T. J., Burgess, J. A. \& Rabinowitz, D. (1966). Sex-determined variation in serum insulin and growth hormone response to amino acid stimulation. Journal of Clinical Endocrinology and Metabolism 26, 791-793.

Merimee, T. J. \& Fineberg, S. E. (1971). Studies of the sex based variation of human growth hormone secretion. Journal of Clinical Endocrinology and Metabolism 33, 896-902.

Merimee, T. J., Lillicrap, D. A. \& Rabinowitz, D. (1965). Effect of arginine on serum-levels of human growthhormone. Lancet ii, 668-670.

Merimec, T. J., Rabinowitz, D. \& Fineberg, S. E. (1969). Arginine-initiated release of human growth hormone. New' England Journal of Medicine 280, 14341438.

Milner, R. D. G. $(1971 \mathrm{a})$. Metabolic and hormonal responses to glucose and glucagon in patients with infantile malnutrition. Pediatric Research 5, 33-39.

Milner, R. D. G. $(1971 b)$. Metabolic and hormonal responses to oral amino acids in infantile malnutrition Archives of Disease in Childhood 46, $301-305$.

Minuto, F., Barreca, A., Adami, G. F., Fortini, P., Monte, P. D., Cella, F., Scopinaro, N. \& Giordano, G. (1989). Insulin-like growth factor- 1 in human malnutrition: relationship with some body composition and nutritional parameters. Journal of Parenteral and Enteral Nutrition 13, 392396.

Mosier, H. D., Jansons, R. A. \& Dearden, L. C. (1985). Increased secretion of growth hormone in rats undergoing catch-up growth after fasting. Growth 49, 346-353.

Nakagawa, K., Ishizuka, T., Obara, T., Matsubara, M. \& Akikawa, K. (1987). Dichotomic action of glucocorticoids on growth hormone secretion. Acta Endocrinologica 116, 165-171.

Nakamoto, J. M., Gertner, J. M., Press, C. M., Hintz, R. L., Rosenfeld, R. G. \& Genel, M. (1986). Suppression of the growth hormone $(\mathrm{GH})$ response to clonidine and GII-releasing hormone by exogenous GH. Journal of Clinical Endocrinology and Metabolism 62, 822826.

Namba, H., Morita, S. \& Melmed, S. (1989). Insulin-like growth factor-I action on growth hormone secretion and messenger ribonucleic acid levels: interaction with somatostatin. Endocrinology 124, 1794-1799.

Netti, C., Guidobono, F., Olgiati, V. R., Sibilia, V. \& Pecile, A. (1981). Histamine agonist and antagonist drugs: interference with CNS control of GH release in rats. Hormone Research 14, 180-191.

Ocrant, I., Valentino, K. L., Hoffman, A. R., Hintz, R. L., Wilson, D. L. \& Rosenfeld, R. G. (1989). Structural characterization and immunohistochemical localization of receptors for insulin-like growth factor II in the rat pituitary gland. Neuroendocrinology 49, 248-254.

O'Sullivan, U., Gluckman, P. D., Breier, B. H., Woodall, S., Siddiqui, R. A. \& McCutcheon, S. N. (1989). Insulinlike growth factor-1 (IGF-1) in mice reduces weight loss during starvation. Endocrinology 125, 2793-2796.

Peters, J. R., Evans, P. J., Page, M. D., Hall, R.. Gibbs, J. T., Dieguez, C. \& Scanlon, M. F. (1986). Cholinergic muscarinic receptor blockade with pirenzepine abolishes slow wave sleep-related growth hormone release in normal adult males. Clinical Endocrinology 25, 213-217.

Phillips, L. S. (1986). Nutrition, somatomedins and the brain. Metabolism 35, 7887

Phillips, L. S. \& Unterman, T. G. (1984). Somatomedin activity in disorders of nutrition and metabolism. Clinics in Endocrinology and Metabolism 13, 145189

Pimstone, B., Barbezat, G., Hansen, J. D. L. \& Murray, P. (1967). Growth hormone and protein-caloric malnutrition. Impaired suppression during induced hyperglycaemia. Lancet ii, 13331334.

Pimstone. B. L.. Barbezat, G., Hansen, J. D. L. \& Murray. P. (1968). Studies on growth hormone secretion in protein-calorie malnutrition. American Journal of Clinical Nutrition 21, 482487.

Pimstone. B. L., Becker, D. \& Kronheim, S. (1975). Disappearance of plasma growth hormone in acromegaly and protein calorie malnutrition after somatostatin. Journal of Clinical Endocrinology and Metabolism 40, 168-171.

Pimstone, B. L., Wittmann, W., Hansen, J. D. L. \& Murray, P. (1966). Growth hormone and kwashiorkor. Role of protein in growth-hormone homeostasis. Lancet ii, 779-780.

Plotsky, P. M. \& Vale, W. (1985). Patterns of growth hormone-releasing factor and somatostatin secretion into the hypophysial-portal circulation of the rat. Science 230, $461-463$.

Press, M., Tamborlane, W. V., Thorner, M. O., Vale, W., Rivier, J., Gertner, J. M. \& Sherwin, R. S. (1984). 
Pituitary response to growth hormone-releasing factor in diabetes: failure of glucose-mediated suppression. Diabetes 33, 804-806.

Quabbe, H.-J., Schilling, E. \& Helge, H. (1966). Pattern of growth hormone secretion during a 24-hour fast in normal adults. Journal of Clinical Endocrinology and Metabolism 26. 1173-1177.

Reichlin. S. (1961). Growth hormone content of pituitaries from rats with hypothalamic lesions. Endocrinology 69. $225-230$.

Reichlin, S. (1983a). Somatostatin: Part I. New England Journal of Medicine 309, 1495- 1502.

Reichlin, S. (1983 b). Somatostatin: Part Il. New England Journal of Medicine 309, 1556-1563.

Richardson. S. B., Hollander, C. S., D'Eletto, R., Greenleaf, P. W. \& Thaw, C. (1980). Acetylcholine inhibits the release of somatostatin from rat hypothalamus in vitro. Endocrinology 107, 122-129.

Rinderknecht, E. \& Humbel. R. E. (1978a). The amino acid sequence of human insulin-like growth factor 1 and its structural homology with proinsulin. Journal of Biological Chemistry 253, 2769- 2776.

Rinderknecht, E. \& Humbel, R. E. (1978b). Primary structure of human insulin-like growth factor II. FEBS Letters 89, 283-286.

Rivier, J., Spiess, J., Thorner, M. \& Vale, W. (1982). Characterization of a growth hormone-releasing factor from a human pancreatic islet tumour. Nature $300,276-278$.

Rosenbaum, M., Fong. Y., Hesse, D. G., Tracey, K. J., Hintz, R. L., Lowry, S. F. \& Gertner, J. M. (1989). Intravenous releeding blocks growth hormone (GH)-provoked rises in serum free fatty acids and blunting of somatotroph response to GH-releasing hormone in normal men. Journal of Clinical Endocrinology and Metabolism 69, 310-316.

Rosenthal, S. M., Hulse, J. A., Kaplan, S. L. \& Grumbach, M. M. (1986). Exogenous growth hormone inhibits growth hormone-releasing factor-induced growth hormone secretion in normal men. Journal of Clinical Investigation 77, 176180

Rosenthal, S. M., Schriock, E. A., Kaplan, S. L., Guillemin, R. \& Grumbach, M. M. (1983). Synthetic human pancreas growth hormone-releasing factor (hpGRF is $_{4}-\mathrm{NH} 2$ ) stimulates growth hormone secretion in normal men. Journal of Clinical Endocrinology and Metabolism 57, 677. 679.

Ross, R. J. M., Borges, F., Grossman, A.. Smith, R., Nhagafoong, L., Rees, L. H., Savage, M. O. \& Besser, G. M. $(1987 \mathrm{a})$. Growth hormone pretreatment in man blocks the response to growth hormone-releasing hormone: evidence for a direct effect of growth hormone. Clinical Endocrinology 26, 117-123.

Ross, R. J. M., Buchanan, C. R., Holly, J., Jones, J., Freeman, E. \& Preece, M. A. (1990). Critically ill patients with low serum IGF-1 and insulin resistance retain the inverse relationship between IGF-Binding Protein-I (IGF-BPl) and Insulin. Journal of Endocrinology Suppl. 123, 127.

Ross, R. J. M., Grossman, A., Davies, P. S. W., Savage, M. O. \& Besser, G. M. (1987b). Stilboestrol pretreatment of children with short stature does not effect the growth hormone response to growth hormonereleasing hormone. Clinical Endocrinology 27, 155-161.

Ross, R. J. M.. Tsagarakis, S., Grossman, A., Nhagafoong, L., Touzel, R. J.. Rees, L. H. \& Besser. G. M. (1987c). GH feedback occurs through modulation of hypothalamic somatostatin under cholinergic control; studies with pyridostigmine and GHRH. Clinical Endocrinologv 27, 727733.

Rosskamp, R., Becker, M., Haverkamp. F.. Thomas, B., Brühl, S.. Klumpp, J. \& Liappis, N. (1987a). Plasma levels of growth hormone-releasing hormone and somatostatin in response to a mixed meal and during sleep in children. Acta Endocrinologica 116, $549-554$

Rosskamp, R.. Becker, M. \& Soetadji, S. (1987b). Circulating somatomedin-C levels and the effect of growth hormone-releasing factor on plasma levels of growth hormone and somatostatin-like immunoreactivity in obese children. European Journal of Pediatrics 146, 48-50.

Rosskamp. R.. Mallmann, R., Liappis, R. \& Soetadjii, S. (1987 ¿). Circulating serum phenylalanine concentrations and the effect of arginine infusion on plasma levels of growth hormone and insulin in treated phenylketonuric children. Acta Endocrinologica 114, 483487.

Rudman, D., Kutner, M. H., Blackston, R. D., Cushman, R. A., Bain. R. P. \& Patterson, J. H. (1981). Children with normal-variant short stature : Ireatment with human growth hormone for six months. New England Journal of Medicine 305, 123-131.

Salmon, W. D. \& Daughaday, W. H. (1957). Hormonally controlled serum factor which stimulates sulfate incorporation by cartilage in vitro. Journal of Laboratory and Clinical Medicine 49, 825836.

Sartin. J. L., Bartol, F. F., Kemppainen, R. J., Dieberg, G., Buxton, D. \& Soyoola, E. (1988). Modulation of growth hormone-releasing factor stimulated growth hormone secretion by plasma glucose and free fatty acid concentrations in sheep. Neuroendocrinology 48, $627-633$.

Scanes, C. G., Griminger, P. \& Buonomo, F. C. (1981). Effects of dietary protein restriction on circulating concentrations of growth hormone in growing domestic fowl (Gallus domesticus). Proceedings of the Society for Experimental Biology and Medicine 168, 334337.

Schlecter, N. L., Russell, S. M., Spencer, E. M.\& Nicoll, C. S. (1986). Evidence suggesting that the direct growthpromoting effect of growth hormone on cartilage in vivo is mediated by local production of somatomedin. Proceedings of the National Academy of Sciences, USA 83, 7932-7934.

Shapiro. B. \& Pimstone, B. L. (1978). Sulphation factor (somatomedin activity) in experimental protein malnutrition in the rat. Journal of Endocrinology 77, 233- 240. 
Sharp, P. S., Foley, K., Chahal, P. \& Kohner, E. M. (1984). The effect of plasma glucose on the growth hormone response to human pancreatic growth hormone releasing factor in normal subjects. Clinical Endocrinology 20, 497-501.

Sheppard, M. C.. Kronheim, S. \& Pimstone, B. L. (1978). Stimulation by growth hormone of somatostatin release from the rat hypothalamus in vitro. Clinical Endocrinology 9, 583586.

Shibasaki, T., Hotta, M., Masuda, A., Imaki, T., Obara, N., Demura, H., Ling, N. \& Shizume, K. (1985). Plasma $\mathrm{GH}$ responses to GHRH and insulin-induced hypoglycemia in man. Journal of Clinical Endocrinology and Metabolism 60, 1265-1267.

Snyder, D. K., Clemmons, D. R. \& Underwood, L. E. (1989). Dietary carbohydrate content determines responsiveness to growth hormone in energy-restricted humans. Journal of Clinical Endocrinology and Metabolism 69, 745--752.

Soliman, A. T., Hassan, A. E. I., Aref, M. K., Hintz, R. L., Rosenfeld, R. G. \& Rogol, A. D. (1986). Serum insulin-like growth factor-1 and factor-2 concentrations and growth hormone and insulin responses to arginine infusion in children with protein energy malnutrition before and after nutritional rehabilitation. Pediatric Research 20, 11221130.

Sopwith, A. M., Penny, E. S., Besser, G. M. \& Rees, L. H. (1985). Stimulation by food of peripheral plasma immunoreactive growth hormone releasing factor. Clinical Endocrinology 22, 337-340.

Sopwith. A. M.. Penny, E. S., Grossman. A.. Savage, M. O.. Besser. G. M. \& Rees, L. H. (1986). Normal circulating immunoreactive growth hormone releasing factor (hGRF) concentrations in patients with functional hypothalamic hGRF deficiency. Clinical Endocrinology 24, 395-400.

Sopwith, A. M., Penny, E. S., Lytras, N., Besser, G. M. \& Rees, L. H. (1987). Dissociation between circulating concentrations of immunoreactive growth hormone releasing factor and growth hormone in normal human subjects. Clinical Science 72, 181185.

Stubbs, W. A., Delitala, G., Jones, A., Jeffcoate, W. J., Edwards, C. R. W., Ratter, S. J., Besser, G. M., Bloom, S. R. \& Alberti, K. G. M. M. (1978). Hormonal and metabolic responses to an enkephalin analogue in normal man. Lancel ii, 1225-1227.

Sukkar, M. Y., Hunter, W. M. \& Passmore, R. (1967). Changes in plasma levels of insulin and growth-hormone levels after a protein meal. Lancet ii, 10201022.

Takahashi, Y., Kipnis, D. M. \& Daughaday, W. H. (1968). Growth hormone secretion during sleep. Journal of Clinical Investigation 47, 20792090.

Tannenbaum, G. S. (1980). Evidence for autoregulation of growth hormone secretion via the central nervous system. Endocrinology 107, 21172120

Tannenbaum, G. S., Guyda, H. J. \& Posner, B. I. (1983). Insulin-like growth factors: a role in growth hormone negative feedback and body weight regulation via brain. Science 220, 77-79.

Tannenbaum, G. S. \& Ling, N. (1984). The interrelationship of growth hormone (GH)-releasing factor and somatostatin in generation of the ultradian rhythm of GH secretion. Endocrinology 115, 1952 - 1957.

Tannenbaum, G. S.. Rorstad, O. \& Brazeau, P. (1979). Effects of prolonged food deprivation on the ultradian growth hormone rhythm and immunoreactive somatostatin tissue levels in the rat. Endocrinology 104, 17331738

Tatár, P. \& Vigaš, M. (1984). Role of alpha,- and alpha,-adrenergic receptors in the growth hormone and prolactin response to insulin-induced hypoglycemia in man. Neuroendocrinology 39, 275-280.

Taylor, A. M., Dunger, D. B., Preece, M. A., Holly, J. M. P., Smith, C. P., Wass, J. A. H., Patel, S. \& Tate, V. E. (1990). The growth hormone independent insulin-like growth factor-1 binding protein BP-28 is associated with serum insulin-like growth factor-1 inhibitory bioactivity in adolescent insulin-dependent diabetics. Clinical Endocrinology 32, 229-239.

Terry, L. C. \& Martin, J. B. (1981). The effects of lateral hypothalamic-medial forebrain stimulation and somatostatin antiserum on pulsatile growth hormone secretion in freely behaving rats: evidence for a dual regulatory mechanism. Endocrinology 109, 622-627.

Thorner, M. O. \& Vance, M. L. (1988). Growth hormone 1988. Journal of Clinical Investigation 82, 745747.

Unger, R. H., Fisentraut, A. M. Madison, L. L. \& Siperstein, M. D. (1965). Fasting levels of growth hormone in men and women. Nature 205, 804-805.

Vance, M. L., Kaiser, D. L., Evans, W. S., Furlanetto, R., Vale, W., Rivier, J. \& Thorner, M. O. (1985). Pulsatile growth hormone secretion in normal man during a continuous 24-hour infusion of human growth hormone releasing factor (1-40). Evidence for intermittent somatostatin secretion. Journal of Clinical Investigation 75. 15841589

Ward, H. C.. Halliday, D. \& Sim. A. J. W. (1987). Protein and energy metabolism with biosynthetic human growth hormone after gastrointestinal surgery. Annals of Surgery 206, 5661.

Waters, M. J., Barnard, R. T., Lobie. P. E., Lim, L., I Iamlin. G., Spencer, S. A., Hammonds, R. G., Leung, D. W. \& Wood, W. I. (1990). Growth hormone receptors - their structure, location and role. Acta Paediatrica Scandinavica Suppl. 366, 6072.

Wehrenberg, W. B., Brazeau, P., Luben, R., Böhlen, P. \& Guillemin, R. (1982a). Inhibition of the pulsatile secretion of growth hormone by monoclonal antibodies to the hypothalamic growth hormone releasing factor (GRF). Endocrinology' 111, 2147-2148. 
Wehrenberg, W. B., Ling, N., Böhlen, P., Esch, F., Brazeau, P. \& Guillemin, R. (1982b). Physiological roles of somatocrinin and somatostatin in the regulation of growth hormone secretion. Biochemical and Biophysical Research Communications 109, 562567.

Wight, P. A., Crew, M. D. \& Spindler, S. R. (1987). Discrete positive and negative thyroid hormone-responsive transcription regulatory elements of the rat growth hormone gene. Journal of Biological Chemistry 262, 5659.5663 .

Williams, T., Berelowitz, M., Joffe, S. N., Thorner, M. O., Rivier, J., Vale, W. \& Frohman, L. A. (1984). Impaired growth hormone responses to growth hormone-releasing factor in obesity: a pituitary defect reversed with weight reduction. New England Journal of Medicine 311, 1403-1407.

Yamashita, S. \& Melmed, S. (1986). Insulin regulation of rat growth hormone gene transcription. Journal of Clinical Investigation 78, $1008-1014$.

Yeoh. S. I. \& Baxter, R. C. (1988). Metabolic regulation of the growth hormone independent insulin-like growth factor binding protein in human plasma. Acta Endocrinologica 119, 465-473.

Ziegler, T.R.. Young, L.S., Manson, J.McK. \& Wilmore, D. W. (1988). Metabolic effects of recombinant human growth hormone in patients receiving parenteral nutrition. Annals of Surgery 208, 6-16. 